\section{WHE BIRTH OF CHEMISTRY}

\section{Vt.}

Latin and English MSS. on Alchenty.-Sources from which the earlier Alchemists acquired knowledge. - Arabic learning during the Middle Ages.-Geber.

IN the last article we discussed the Greek MSS. on Alchemy, and endeavoured to show that, owing to the uncertainty of their age and the obscurity of their authorship, they are less important components of the early history of chemistry than some writers have laboured to prove them.

There exist also many MSS. in Arabic and Persian on alchemy, but in all probability few of them are earlier than the 8th century. The Library of El Escorial is undoubtedly more rich in such MSS. than any existing library; but from the imperfect manner in which its treasures are catalogued, we are unable even to give a list of the more important of these treatises. The British Museum contains several Arabic MSS. on alchemy, written about the I 2 th century. Such of these as we have seen are devoid of drawings, and apparently also of symbols.

Early MSS. on alchemy in Latin exist in all large libraries. They contain various recipes for making the philosophers' stone, " secrets of art," copies of the inscription of the Smaragdine table, with the interpretation thereof, and an infinite amount of unintelligible nonsense. They differ in no respect from the later printed treatises on alchemy, which we shall presently discuss in detail. The matter of most of the MSS. is to be found in printed works compiled by alchemists of the $15^{\text {th }}$ and 16 th centuries.

One of the oldest alchemical MSS. In the British Museum is a transcript of the Speculum Secretorum of Roger Bacon, who died in 1284. It is in the Sloane Collection, and was written towards the end of the 13 th century, say between 1290 and 1300 . There is no autograph MS. of Roger Bacon either in the British Museum or in the Record Office; the MS. in question was copied by an unknown man. The following woodcut represents a few lines of the commencement of the MS.

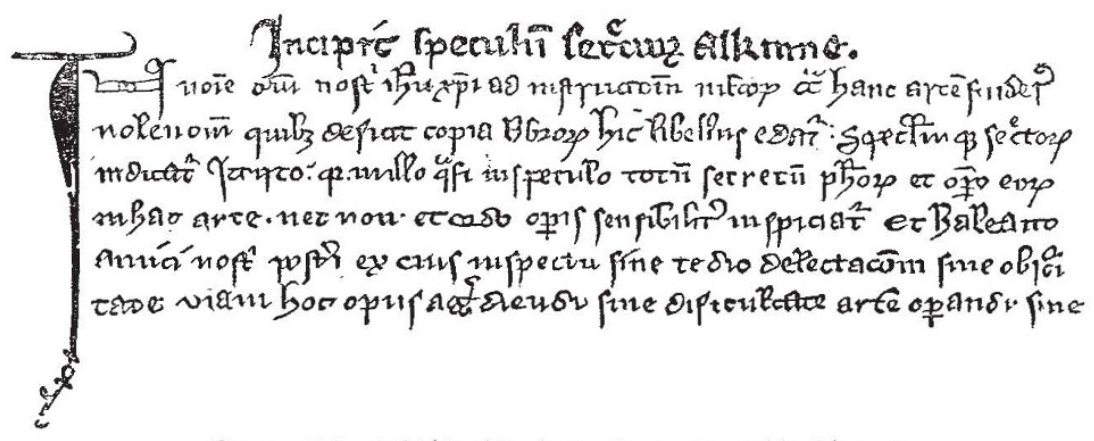

FIG. 8. - Alchemical MS. of the thirteenth century. - British Museum.

The above reads as follows:-_"Incipit speculum secretorum alkimix. In nomine Domini Nosiri Jesu Christi ad instructionem multorum circa hanc artem studere volentium, quibus deficit copia librorum, hic libellus edatur, speculumque,secretorum indicatur, idcirco quia in illo, quasi in speculo, totum secretum philosophorum et operatio eorum in bac arte, nec non et ordo operis, sensibiliter inspiciatur. Et habeant amici nostri posteri ex ejus inspectu sine tedio delectationem, sine obscuritate viam hoc opus aggrediendi, sine difficultate artem operandi." The translation is as follows :- "In the name of our Lord Jesus Christ, for the information of the many who wish to devote themselves to the study of this art, and who lack a supply of books, this small manual is published, and is entitled the "Mirror of Secrets,' seeing that in it, as in a mirror, the whole secret of philosophers and their working in this art-nay more, the process of their work-may be visibly discerned. And may our friendly descen dants obtain from the perusal of it unwearied delight, a clear path for taking this work in hand, and a mode of operation unnampered by obstacles."

Among the earlier English MSS, on Alchemy in the British Museum is one which, the Preface informs us, was done "at the iastance and prayer of a poure creature, and to the helping of man, I, Malmedis, being at greete uneased in prisone, have thees forseide bokes hidre to itake a hand, and so I shal fynnysshe hit, to God be the laude and preisyng."

The following woodcut (Fig. 9) represents a portion of this MS. relating to mercury ${ }^{*}:-$

It will be noted that mercury, together with sulphur, and the "rede stoone," is designated the producer of all metals; we also observe an allusion to the Aristotelian theory of the elements (of which an account has been given in the second of these articles) in the assertion that mercury is "hotte and moyste." This MS. is in the Sloane collection, and is well preserved, and written on vellum.

Let us now turn our attention to the dogmas of the alchemists and early chemists, as set forth in the numberless printed books on the subject.

We must bear in mind at the outset that chemistry and alchemy--understanding by the former legitimate inquiry into the nature of different kinds of matter, and by the latter the

* We must express our great indebtedness to Mr. Maunde Thompson, of he British Museum, fo- allowing us ready access to the MSS. department. futile attempts to make gold-existed side by side in the same age, often in the same person. We cannot agree with M. Hoefer when he says, "La chimie du moyen âge, c'est l'alchimie," because some of the early chemists were not alchemists, and the crude processes of the one often led to the exact processes of the other, Lord Bacon in the "De Augmentis Scientiarum," has some very pertinent remarks regarding alchemy :-_" Credulity in arts and opinions," he remarks, "is likewise of two kinds, viz., when men give too much belief to arts themselves, or to certain authors in any art. The sciences that sway the imagination more than the reason are principally three, viz., Astrology, Natural magic, and Alchemy. . . . Alchemy may be com pared to the man who told his sons that he bad left them gold, buried somewhere in his vineyard; where they by digging found no gold, but by turning up the mould about the roots of the vines, procured a plentiful vintage. So the search and endeavours to make gold have brought many useful inventions and instructive experiments to light.'

The heritage which the alchemists and early chemists received from the ancients was by no means insignificant ; for they possessed all the experience accumulated by the ancients in the various arts and processes which we have before described; and of theoretical matter they possessed, adopted, and prized, the theory of the transmutation of the elements proposed by Aristotle. Of works bearing upon the history of matter they had the writings of Aristotle, Dioscorides, Lucretius, Archimedes, Hero, Vitruvius, and Pliny. Few books are quoted more often in alchemic treatises than the "Natural History" of Pliny; and we sometimes find an almost verbatim transcript of certain portions of this work. The alchemists can therefore scarcely be said to have created a science, for the science of their day is linked with that of the ancients.

When ancient learning had almost died out, and Europe was, intellectually, in a state of complete darkness, the Arabians were the most cultivated people in the world. It is to Arabia that we must look for the origin of several sciences which we are wont to attribute to other nations. The Arabians instituted universities, observatories, public libraries, and museums ; they collected together all the remains of ancient learning, and through their medium the greater number of Greek and Latin authors which were read during the Middle Ages were known to Europe. In the eighth century the Arabs had full possession of Spain, 
and at a somewhat later date this country possessed the nost famous universities in Europe. The Arabs, in propagating their new religion, propagated also the remains of ancient culture, which had already been introduced into Persia and Syria by the Nestorians, who had founded a school of great reputation at Wdessa. Again, when Justinian closed the schools of Athens and Alexandria, many of the professors fled to Persia and Arabia, and formed new centres of learning. The works of many atthors, including Aristotie, Dioscorides, and Pliny, were soon translated into Arabic and Persian, and beoame widely diffused. "Ce fut," remarks M. Figuier, "ainsi que de l'Inde jusqu'à l'Espagne, des rivages du 'Tigre jusqu'à ceux du Guadal. quivir, les livres de science se propagèrent parmi des peuples qui avait déjà une littérature, une philosophie religieuse, et qui n'étaient point dépourvus d'imagination."

In the eighth century the University of Bagdad was founded

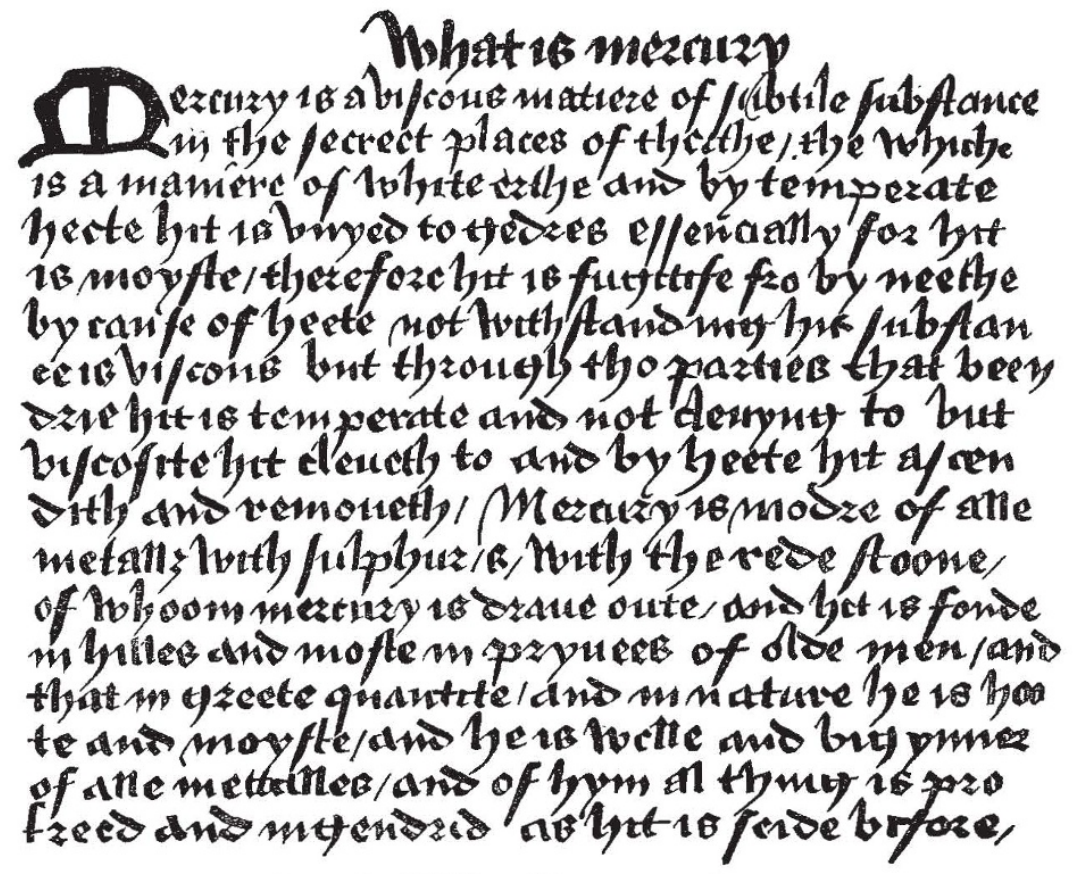

FiG. 9.-English MS. on Alchemy,-Fifteenth century.

by the Caliph Al-Mansor, and in the following century it attained a the-eminent position. A large medical school was connected with it, also hospitals and laboratories. The Caliph AI-Mamoum with in made to erected an observatidian. It is said that at one time the measure an arc of the meridian. It is said that at ousand students. In it the sciences found a home, and every scrap of ancient learning was eagerly collected and often extended. When the Arabic empire was broken up by internal dissersions into a number of small states, the University of Bagdad, losing the powerful smanl states, the Caliphs, fell into decay, and soon ceased to be patronage of the Caliphs, fell into decay, and soon Cairo in the known. A somewhat celebrated school arose in Cairo in the tenth century, but we possess but few particulars concerning it. We soon hear of Spast fluurishing country in Europe, both incentury this was the most flutrishing country in Europe, both intellectuaily and otherwise. The University of Cordova possessed great celebrity, and students flocked to it from all parts 000,000 world. It contained a library of between 200,000 and $300, \infty 00$ volumes, an unusually large collection of books prior to the invention of printing. The Arabians were great mathematicians known as Albategnius) among the twenty greatest astronomers who have ever lived. Again, Alhazen wrote a treatise on optics in the eleventh century, and there were many treatises on botany in the elevent The Arabs made but little advance in anatomy and medicine. The Arabs made but little advance in anatomy however, because

the human body.

After the above remarks it is almost needless to say that we must look to Arabia for the earliest treatises on alchemy and chemistry. Indeed the Arabians cultivated the latter science with success, and the first work on the subject with whic'. we with success, and the written by Yeber-Abou-Moussah-Djafer-alSofi, whom we call Geber, an Arab of the eighth century. Tofi, whad, no doubt, been writers on chemistry before his time, There had, no doubt, been wre. We have endeavoured to prove in the preceding article that the Greek MSS. on the "sacred art" are not trustworthy evidences of the early origin of the science; and we cannot tell from what source Geber acquired any of his knowledge. He alludes to no one by name, but we know that

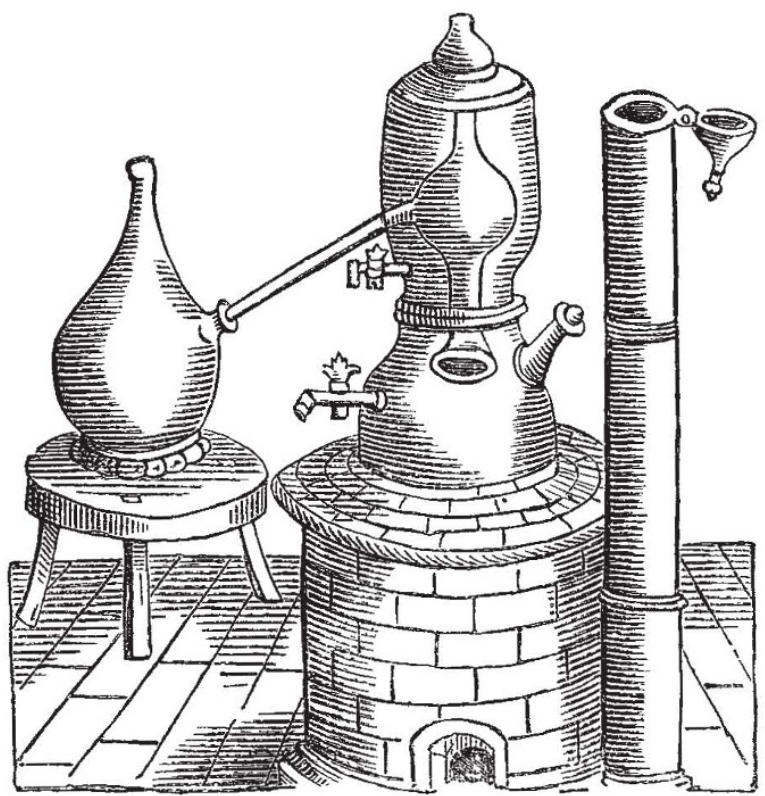

Fig, xo

the Arabians collected knowledge from every source--Egyptian, Indian, Persian, Greek, and Roman. It is thought by soma 
that Geber acquired some of his notions of chemistry from Egypt.

Several MSS., purporting to contain the writings of Geber, exist in various libranes in Europe; these were translated into Latin as early as the year 1 529, and into English in 1678 . We have reason to believe that the Latin translation was faithfully done, if the Arabic text be not corrupt. The work consists of four treatises:- $(\alpha)$ Of the search for Perfection, $(\beta)$ Of the Sum of Perfection, $(\gamma)$ Of the Invention of Verity, and $(\delta)$ Of Furnaces. Geber was acquainted with the seven metals known to the ancients, and he regarded gold, silver, copper, iron, tin, and lead, as compounds of mercury with sulphur in different proportions. Gold and silver are the most perfect metals, and are composed of the purest mercury and sulphur; the other metals consist of less pure mercury and sulphur, but may be converted into gold and silver by purifying their constituents, and uniting them in different proportions. He also describes various chemical substances, among others the following. The carbonates of potash and soda were known to Geber, and were procured from the ashes of plants. Caustic soda was procured from the carbonate by heating its solution with quicklime, as in the present day. Common salt was purified by ignition, solution, and filtration, and the solution was afterwards evaporated, and the salt crystallised out. Nitrate of potash, or saltpetre, and chloride of ammonium, or sal ammoniac, were apparently common in Geber's time; as also were alum, borax, and green copperas, or protosulphate of iron. Geber procured nitric acid by distilling copperas, saltpetre, and alum, and he used the acid for dissolving silver, and when mixed with sal ammoniac for dissolving gold. He obtained nitrate of silver in the form of crystals, and noticed their fusibility. Various compounds of mercury are described, among others corrosive sublimate or chloride of mercury, cinnabar or sulphide of mercury, and the red oxide of mercury, in which, mearly ten centuries later, oxygen gas was discovered by Dr. Priestley. Geber also obtained sulphuric acid by distilling alum. He appears to have been acquainted with the various processes of distlllation, sublimation, calcmation, filtration, and many others ; indeed, with almost all the processes practised by his successors during the succeeding eight or nine centuries.

It is probable that some of the processes described by Geber were worked out in the medical schools of Arabia, and were known shorily before bis time; yet he was himself a patient worker, and often intersperses his descriptions of substances and processes with remarks on the method of experimenting, and the mode of thought most suitable for the studies which he describes. He has often been called the "Founder of Chemistry ;" at least his works are the earliest with which we are acquainted, and he was venerated as Master alike by the alchemists and chemists of the Middle Ages.

Geber appears to have been acquainted with many chemical appliances. In the earliest translations of his works we find figures of various furnaces and forms of distillatory apparatus; one of them, not unlike a still now in use, is represented above. The greater number of vessels described and figured by Baptiste Porta in his treatise De Distillationibus, published in 1609 , are to be found in the first Latin translations of the works of Geber. G. F. RODWELL

\section{THE ARCTIC EXPEDITION}

$T H E$ following is the text of the reply of the Grovernment to the deputation which recently had an interview with Mr. Lowe and Mr. Goschen :-

"II, Downing Street.

"Dear Sir Henry Rawlinson,-Mr. Goschen and I have carefully considered the documents which you have laid before us with regard to the proposed Arctic Expedition.

"We do not find in them anything which shows that there is any pressing reason why the expedition should be sent this year.

"We give no opinion as to the expediency of such an expedition at a future time, but we are clearly of opinion that it would not be right to send out a second scientific expedition precisely at the moment when the public revenue has to bear the main burden of the expenses of the operations intrusted to the Challenger.

"I believe it has been erroneously stated that the
Challenger Expedition involves very little expense. That is not so. The cost has already been considerable, and nothing has been spared to insure success; there will further be an additional annual outlay for three years.

"Under these circumstances, we regret that we cannot recommend the sending an exploring party to the Arctic Ocean as a Government enterprise this year.

$$
\begin{aligned}
& \text { "Believe me, yours very truly, } \\
& \text { "ROBERT LowE. }
\end{aligned}
$$$$
\text { "Sir Henry C. Rawlinson, K.C.B." }
$$

It is clear, we take it from this, that it only remains for the men of science to make out their case, and we believe that the Arctic Committee are fully alive to this. The Daily News in a leader has indicated what we had already ventured to suggest as the weak point of the appeal, namely that it was incomplete, and that many men of science knew nothing of the proposed expedition. But in doing this we had no intention to cast a slur upon the Geographical Society; on the contrary we think that that Society's action in this matter is one which the Royal Society could now follow with the greatest advantage to science, and which we hope it will follow.

In I 865 the Geographical Society begged the Royal Society to take the lead in this matter, but the Royal Society Council declined. In 1872 the Geographical Society again entreated the Royal Society to take the matter up, but again received a chilling reply to the effect that the Royal Society Council would be prepared to give advice when applied to by the Government.

The Geographical Society then did the next best thing. It applied to other leading scientific societies, and to some few scientific men for statements of results to be derived from Arctic exploration. These it received and laid before Government, without giving any undue prominence to purely geographical results.

It is clear, therefore, that it is now the duty of the Royal Society and the other societies at once to add their influence to the movement; let a joint committee be formed to report, if need be, to the various councils. In this way the knowledge posessed by all specialists ought to be made available for the common good, so that a complete statement may be forwarded to the Government in the summer to enable the officers of the expedition to be appointed in time to avail themselves of special training.

\section{NOTES}

THE recent fusion of the Ethnological and Anthropological Societies under the designation of "the Anthropological Institute of Great Britain and Ireland," not only did good service to science but has financially proved thus far so successful that the Report of the Council for 1872 , to be presented to the members next Tuesday evening at the annual meeting, announces a handsome surplus income applicable to the reduction of liabilities incurred in former years. In this promising condition of financial prosperity it is all the more to be deplored that a serious dissension has arisen in the Council in reference to the nomination of a successor to Sir John Lubbock, who, to the universal regret of the members, vacates the presidential chair, under the pressure of parliamentary and other engagements. Touching this matter we have received a copy of a printed statement signed by Mr. Harris and seven other members of Council, which alleges that at a Council Meeting, held on the I th of last month, Dr. Charnock was placed on the House List for 1873, but that at a succeeding Council Meeting of January 7 , this nomination was rescinded and the House List recast with the substitution of Professor Busk as President in the place of Dr. Charnock. This recasting of the List is made a matter of protest, and the members of the Institute, with whom the final decision rests, are appealed to. $\ldots$ We need hardly remark that 